ISSN 0258-7122

Bangladesh J. Agril. Res. 35(3) : 439-451, September 2010

\title{
SURVEY ON POSTHARVEST PRACTICES AND LOSSES OF LITCHI IN SELECTED AREAS OF BANGLADESH
}

\author{
M. M. MOLLA ${ }^{1}$, M. N. ISLAM ${ }^{2}$, T. A. A. NASRIN ${ }^{3}$ \\ AND M. A. J. BHUYAN ${ }^{4}$
}

\begin{abstract}
A survey was conducted to assess the postharvest practices and lossess of litchi during May to June 2008. Three litchi growing areas viz., Dinajpur, Ishurdi, and Natore, two urban areas, namely, Dhaka and Gazipur were selected for this study. Some indigenous postharvest practices were observed to follow in all the growing areas mostly by the growers and/or beparies those are involved in harvesting. These practices were as pre-cooling by keeping the harvested fruits under the shade of the trees, sorting based on damaged, pest infested, and disease infected fruits and so called believed cooling with litchi leaves during transportation. Nobody practices the grading of fruits. The usual packaging practices were observed mainly with bamboo baskets lining with litchi leaves and covering with gunny sheets. None of the aradthdars involved in packaging .The postharvest losses were reported mainly at harvesting (8.0\%), handling from orchard to selling point by the growers and beparies involved in harvesting (4.61\%) and after buying to consumption by the consumers (7.5\%). Considering the channels involved in litchi marketing, the growers and/or beparies engaged in harvesting had the highest percent of losses (16\% in Dinajpur, 12\% in Ishurdi, and $11 \%$ in Natore) followed by the consumers (7.5\%).
\end{abstract}

Keywords: Litchi, harvesting practices, mode of packaging and transportation and postharvest losses.

\section{Introduction}

Litchi (Litchi chinensis Sonn) is one of the popular and delicious fruits of Bangladesh. It is grown almost all over the country but its production is mostly concentrated in the northern and eastern region (Anon., 2006). The leading litchis producing districts are Dinajpur, Rajshahi, Pabna, Jessore, Mymensingh, and Chittagong areas. At present, the area of this fruit under cultivation is 1681 hectares and production is 40195 metric tonnes (Anon., 2006). A considerable amount of litchi fruits losses every year during harvesting, sorting, storing, transportation, selling and consumtion due to its perishability. The perishability of this fruit is attributed to immense physiological changes after harvest (Momen et.al., 1993). Amiruzzaman (1990) reported that the magnitude of postharvest

\footnotetext{
${ }^{1 \& 3}$ Scientific Officer, Postharvest Technology Section, HRC, Bangladesh Agricultural Research Institute (BARI), Gazipur, ${ }^{2}$ Senior Scientific Officer, Postharvest Technology Section, HRC, Bangladesh Agricultural Research Institute (BARI), Gazipur, ${ }^{4}$ Director, TCRC, Bangladesh Agricultural Research Institute (BARI), Gazipur, Bangladesh.
} 
losses in fresh fruits including litchi in Bangladesh is 25-50\%, while it is only 5$25 \%$ in developed countries (Khader, 1992). For developing an effective postharvest handlig and packaging technique to minimize the postharvest losses, it is necessary to know the actual causes of postharvest losses at poverty- stricken farmers, whole sellers, and retailers level. Postharvest handling, packaging and storage of fruits are important because they affect the postharvest quality and quantity of produce. However, very little information on the postharvest practices and losses of litchi at growers, arathdars, pikars, beparies, retailers, and consumers level. With this views in mind, the present study was conducted to know the existing postharvest practices and losses of litchi fruits at different levels, which will help for developing appropriate postharvest practices to reduce its losses.

\section{Materials and Method}

\section{Selection of study areas}

The present study was conducted in three intensive litchi growing areas viz., Dinajpur, Ishurdi, Natore, and two urban areas, namely, Dhaka and Gazipur. Ten each of growers, arathdars, beparis, and retailers were selected from each growing area for getting answers using with pre-tested questionnaires. Equal number of arathdar, beparies, and retailers were selected in the urban marketing areas of Dhaka. Consumers were selected only in two urban areas from Dhaka and Gazipur.

\section{Methods of data collection and analysis}

Data on postharvest practices and losses with other relevant factors were collected from the above regions during the harvesting season of litchi in May to June 2008. The collected data were summarized, compiled, and analyzed.

\section{Preparation of survey schedules}

In order to collect data from personnel involved in litchi handling and marketing, six different questionaires were prepared for growers, arathdars (wholesalers), pikars, beparies, retailers, and consumers. The schedules were pre-tested and necessary modifications were made for ensuring consistency and applicability in actual field condition.

\section{Definition of respondents}

Grower: Growers produce litchi and sell their produce to the beparies through arathdar. Sometimes, they sell their expected crops directly to the beparies based on orchard areas i.e., number of productive trees in the orchard. In order to avoid management cost and risk, some growers sell their expected crops to the beparies 
during the flowering and fruiting stage or even before on the basis of estimation of the amount of bloom in the trees.

Bepari: Beparies are either local person or coming from other districts like Dhaka, Chittagong, Khulna, Jessore, Barisal etc. Depending on involvement in harvesting, they are of two groups. One of them involved in harvesting but other one is not. The first group of beparies bought harvested litchi from growers and other intermediates in the local markets through the local arathdars, while the second group of the beparies bought advance crops (orchards) directly from the growers or other intermediates and harvest litchi by their own management. Both groups of beparies despatch litchi mostly to arathdars to other big markets.

Arathdar: Arathdars are big traders. They are commission agent those have a fixed establishment in the market and operated between beparies and pikars or retailers. They took commission from growers and beparies.

Pikar: Pikars are intermediatries between arathdars and retailers. This group of litchi traders have a permanent shop in certain location mostly found in urban or city areas. They buy large amount of litchi from arathdars and sell it to retailers in their locations.

Retailer: Retailer is last link in the litchi marketing. Retailers have permanent or seasonal shop in the local bazars or urban or city markets. Retailers in growing areas buy litchi directly from the growers or beparies or from beparies through arathdars. But, retailers in urban or city areas bought litchi from arathdars or pikars working in their locality and sell it to the residents, the ultimate consumers.

Consumer : The people, who buy litchi for consumption, are known as consumer. They are the last outlet of this survey. Usually they buy litchi from retailers.

\section{Results and Discussion}

\section{Cultivars grown in selected growing areas}

Growers at different locations cultivated different commercial cultivars of litchi. The growers mentioned that these were Bombai, Madrazi, Mozaffarpuri, China3, and Bedana. In Dinajpur, growers cultivated 50\% Bombai, 30\% Madrazi, 10\% China-3, and $10 \%$ Bedana cultivars, while growers of Natore had cultivated $70 \%$ Bombai, 20\% Madrazi, and 10\% China-3 in Ishurdi. In Natore, the growers cultivated 30\% Bombai, 10\% China-3, 10\% Madrazi, and 50\% Mozaffarpuri cultivars of litchi (Table 1 ). 
Table 1. Litchi varieties cultivated by the growers.

\begin{tabular}{|c|c|c|c|}
\hline \multirow{2}{*}{ Cultivars } & \multicolumn{3}{|c|}{ Cultivars cultivated by growers (as percentage) } \\
\hline & Dinajpur & Ishurdi (Pabna) & Natore \\
\hline Bombai & 50 & 70 & 30 \\
\hline China-3 & 10 & 10 & 10 \\
\hline Madrazi & 30 & 20 & 10 \\
\hline Mozaffarpuri & - & - & 50 \\
\hline Bedana & 10 & - & - \\
\hline Total & 100 & 100 & 100 \\
\hline
\end{tabular}

\section{Identification of maturity and selection of harvesting stage based on fruit colour}

Cent percent respondents in all the three locations informed that fruit size and colour were the selection criteria of maturity index of litchi fruits. Among fruit size, colour and dots on fruit skin, colour was the most predominant criterion for selection of harvesting. Most of the respondents (70-100 \%) harvested litchi when attains $75-100 \%$ colour on fruit skin (Table 2). Some of the respondents (20-30\%) also reported that fruits could be harvested at 50\% colour attains on fruit skin for distant marketing. They reported that fruits harvested before colour breaking were not suitable for marketing, as it did not ripe properly. It is an agreement with non-climacteric nature of litchi fruits. Underhill et al. (1997) stated that litchi is a non-climacteric fruit and as such does not ripe once harvested.

Table 2. Maturity identification and selection of harvesting stage based on fruit colour.

\begin{tabular}{l|l|l|l|l|c|c|c}
\hline \multirow{2}{*}{ Location } & \multicolumn{3}{|c|}{$\begin{array}{c}\text { Basis of maturity identification } \\
\text { (\% of respondents) }\end{array}$} & \multicolumn{4}{|c}{$\begin{array}{c}\text { Harvesting stage based on fruit colour } \\
\text { (\% of respondents) }\end{array}$} \\
\cline { 2 - 8 } & Fruit size & Colour & $\begin{array}{c}\text { Dots on } \\
\text { fruit skin }\end{array}$ & $\begin{array}{c}\text { Colour } \\
\text { breaking }\end{array}$ & $\begin{array}{c}25 \% \\
\text { colour }\end{array}$ & $\begin{array}{c}50 \% \\
\text { colour }\end{array}$ & $\begin{array}{c}75-100 \% \\
\text { colour }\end{array}$ \\
\hline Dinajpur & 100 & 100 & 100 & - & - & 30 & 70 \\
Ishurdi & 100 & 100 & 30 & - & - & 20 & 80 \\
Natore & 100 & 100 & - & - & - & - & 100 \\
\hline
\end{tabular}

\section{Harvesting period and time of harvest on the day}

Table 3 indicated that harvesting period of the litchi varied from 16 May to 15 June in a year in all the growing areas of Dinajpur, Ishurdi, and Natore. In Natore areas, about 55\% harvesting was done during 16 May to 31 May, while it was 40 and $45 \%$ in Ishurdi and Dinajpur. Concerned growers and beparies reported that 
harvesting periods varied mostly on the maturity stage of the different cultivars and some extent on desire to get more benefits depends on market situation. They reported that early and late marketing are more profitable. Most of the cases, fruits were harvested early in the morning in a day (Table 3). Sometimes, harvesting late in the afternoon depend, on the purpose of marketing or agreement to the beparies from distant location. The harvested litchis were carried from the orchards to the local selling points on the day or just in the next morning. Then the litchis were packed and dispatched to the distant markets as early as possible. Usually it took 1 to 2 days only.

Table 3. Harvesting period and time of harvest on the day.

\begin{tabular}{l|l|l|l|l|l|l}
\hline \multirow{2}{*}{ Location } & \multicolumn{4}{c|}{ Harvesting period (\% over total harvesting) } & \multicolumn{2}{c}{$\begin{array}{c}\text { Time of harvest on the } \\
\text { day (\% of respondents) }\end{array}$} \\
\cline { 2 - 7 } & $\begin{array}{l}\text { 01 May- } \\
\text { 15 May }\end{array}$ & $\begin{array}{c}\text { 16 May- } \\
\text { 31 May }\end{array}$ & $\begin{array}{c}\text { 01 June- } \\
\text { 15 June }\end{array}$ & $\begin{array}{c}\text { 16 June- } \\
\text { 30 June }\end{array}$ & Morning & Afternoon \\
\hline Dinajpur & 5 & 45 & 45 & 5 & 70 & 30 \\
Ishurdi & 5 & 40 & 40 & 5 & 80 & 20 \\
Natore & 5 & 55 & 40 & - & 70 & 30 \\
\hline
\end{tabular}

\section{Postharvest practices}

Some indigenous postharvest practices were observed to follow in all the growing areas mostly by the growers and/or beparies those are involved in harvesting. These practices were pre-cooling by keeping the harvested fruits under the shade of the trees, sorting based on damaged, pest infested, and disease infected fruits, packaging with bamboo baskets, gunny sheets, and lining with litchi leaves during transportation.

The percents of growers, beparies, arathdars, and retailers followed indigenous postharvest practices like pre-cooling, sorting, grading, cooling with litchi leaves and packaging are presented in Table 4. It was reported that $100 \%$ growers performed pre-cooling by keeping the harvested fruits under the shade of the trees in Dinajpur, Ishurdi, and Natore. Sorting of litchi was practiced by $100 \%$ of growers involved in harvesting and $60 \%, 50 \%$, and $65 \%$ of beparies those are involved in harvesting in three locations (Dinajpur, Ishurdi, and Natore), but none of them followed grading. The growers those are involved in harvesting followed packaging practices. Both groups of beparies involved or not involved in harvesting followed packaging. The usual packaging practices were mainly with bamboo baskets lining with litchi leaves and covering with gunny sheets (Fig.1). None of the arathdars involved in packaging. The beparies opined that packaging with litchi leaves help lower temperature that keeps the quality of fruits during transportation. It is an agreement with Maiti (1985). He reported that litchi harvested with a portion of branch and few leaves helps in pruning the 
trees and improving the keeping quality during storage of the fruits with pruned twigs and leaves.

Table 4. Postharvest techniques used by the respondents.

\begin{tabular}{|c|c|c|c|c|c|c|c|c|c|c|c|c|c|c|c|}
\hline \multirow{2}{*}{ Particulars } & \multicolumn{4}{|c|}{ Dinajpur } & \multicolumn{4}{|c|}{ Ishurdi } & \multicolumn{4}{|c|}{ Natore } & \multicolumn{3}{|c|}{ Dhaka } \\
\hline & Gr & $\mathrm{Be}$ & $\mathrm{Ar}$ & $\mathrm{Re}$ & $\mathrm{Gr}$ & $\mathrm{Be}$ & $\mathrm{Ar}$ & $\mathrm{Re}$ & $\mathrm{Gr}$ & $\mathrm{Be}$ & $\mathrm{Ar}$ & $\mathrm{Re}$ & $\mathrm{Be}$ & $\mathrm{Ar}$ & $\mathrm{Re}$ \\
\hline *Pre..cooling & 100 & 100 & - & 10 & 100 & 100 & - & - & 100 & 100 & - & - & - & - & - \\
\hline Sorting & 100 & 60 & - & - & 100 & 50 & - & - & 100 & 100 & - & - & - & - & - \\
\hline Grading & - & - & - & - & - & - & - & - & - & - & - & - & - & - & - \\
\hline $\begin{array}{l}\text { *Cooling } \\
\text { (with litchi } \\
\text { leaves) }\end{array}$ & 100 & 100 & - & - & 100 & 100 & - & - & 100 & 100 & - & - & - & - & - \\
\hline Packaging & 30 & 100 & - & - & 40 & 100 & - & - & 40 & 100 & - & - & - & - & - \\
\hline
\end{tabular}

Gr=Grower, $\mathrm{Be}=$ Bepari, Ar Arathdar, Re Retailer, * Local methods

\section{Transportation methods}

Method of transportation depends on the volume of produce handled and distance of market from the growing area. Growers having small quantity of marketable litchi generally used manually operated tri-cycle, locally called van and another locally made tri-cycle operated by shallow-engine, locally called Nosimon, whereas for large volume, both growers and intermediaries (bepari) used bus and truck for long distant marketing (Fig. 1) . On an average, 5 to $10 \%$ of growers carried litchi on head load but $50 \%, 70 \%$, and $30 \%$ of growers carried it by van or rickshaw van, whereas $0 \%, 25 \%$, and $60 \%$ of growers carried harvested litchi by Nosimon in Dinajpur, Ishurdi and Natore, respectively. For long distant marketing, 30 to $40 \%$ of beparies carried litchis solely or with other commodities by truck from local market to urban wholesalers i.e., aradthdars. About 40 to $55 \%$ beparies despatched litchi by using top roof of the passenger bus from local growing areas to different urban or litchi deficient areas in the country (Table 5). Pikars, the intermediaries sale litchi to retailers, were found only in Dhaka City in the study areas. They carried litchis rickshaw van (30\%, CNG-auto rickshaw (50\%) and city local bus (20\%). In the case of retailer, the corresponding figures for van or rickshaw van were $90 \%, 75 \%$, and $60 \%$ in the growing areas, but it was $70 \%$ in Dhaka City. 
Table 5. Transportation method of litchis for marketing.

\begin{tabular}{|c|c|c|c|c|c|c|c|c|c|c|c|c|c|}
\hline \multirow{3}{*}{ Particulars } & \multicolumn{13}{|c|}{ Percent of total respondents } \\
\hline & \multicolumn{7}{|c|}{ Dinajpur } & \multicolumn{6}{|c|}{ Ishurdi } \\
\hline & $\mathrm{HL}$ & V/RV & NM & BS & TR & BT & $\mathrm{RL}$ & HL & V/RV & NM & BS & TR & BT \\
\hline Grower & 5.0 & 50 & 45 & - & - & - & - & 5.0 & 70 & 25 & - & - & - \\
\hline Bepari & - & 20 & - & 50 & 40 & - & 10 & - & 50 & 50 & 55 & 45 & - \\
\hline Pikar & & & & & & & & & & & & & \\
\hline Retailer & - & 90 & - & 10 & - & - & - & - & 75 & 20 & 5 & - & - \\
\hline
\end{tabular}

HL=Head load, V/RV= Van/Rickshaw Van*, NM=Nosimon** BS= Bus, TR=Truck, BT= Boat and RL=Rail

*Van/Rickshaw Van -Tri-cycle operated manually **Nosimon-A local made tri-cycle operated by shallow- engine.

Table 5. Transportation method of litchis for marketing (Cont'd.)

\begin{tabular}{l|l|l|l|l|l|l|l|l|l|l|l|l|l}
\hline \multirow{2}{*}{ Particulars } & \multicolumn{10}{c}{ Natore } & \multicolumn{10}{c}{ Dhaka } \\
\cline { 2 - 16 } & HL & RV/V & NM & BS & TR & BT & RL & HL & RV/V & $\begin{array}{c}\text { AR- } \\
\text { CNG }\end{array}$ & BS & TR & BT \\
\hline Grower & 10 & 30 & 60 & - & - & - & - & - & - & - & - & - & - \\
Bepari & - & 40 & 60 & 40 & 60 & - & - & - & - & - & - & - & - \\
Pikar & - & - & - & - & - & - & - & - & 30 & 50 & 20 & - & - \\
Retailer & - & 60 & 30 & 10 & - & - & - & - & 70 & 20 & 10 & - & - \\
\hline
\end{tabular}

HL=Head load, $\mathrm{V}=$ Van, NM=Nosimon, $\mathrm{BS}=$ Bus, $\mathrm{TR}=$ Truck, $\mathrm{BT}=$ Boat, $\mathrm{RL}=$ Rail, $\mathrm{AR}=$ Auto Rickshaw

*Van-Tri-cycle operated manualy **Nosimon-A local made tri-cycle operated by shallow-engine, AR-CNG***=Auto Rickshaw fueled with Compressed Natural Gas

The road communications as well as telecommucation system among growing areas and distant markets were quite good in the surveyed areas. The beparies tried their best to send the harvested litchi to aradthdars in city areas within a short time. So, the postharvest losses of litchis were not much more for despatching time. But, the practices despatching litchis with other commodities in the truck or on the roof of the bus is not a scientific method of transportation. A portion of transported litchis was found to damage due to the lack of standard packaging couple with default method of transportation.

Postharvest losses of litchi at various groups of respondents with respect to different stage of handling/point of marketing

Losses during harvesting: The losses of litchi were estimated based on the response of respondents. The average losses of litchi during harvest areas were found about $10 \%, 8 \%$, and 6\% (Table 6) in Dinajpur, Ishurdi, and Natore respectively .The grand average postharvest losses of litchi in the growing areas 
during harvesting was $8.00 \%$. According to the growers' opinion, these losses were mostly due to disease and pest infestation at preharvest condition but expressed at harvesting period. They also reported that a small portion of these losses was also due to improper techniques or lack of care during manual harvesting. Growers or agents of beparies practiced handpicking for harvesting of litchi. Sometimes adverse weather condition, especially high temperature may cause browning of fruit skin and aril spoilage on the trees as well as harvested fruits (Fig. 1).

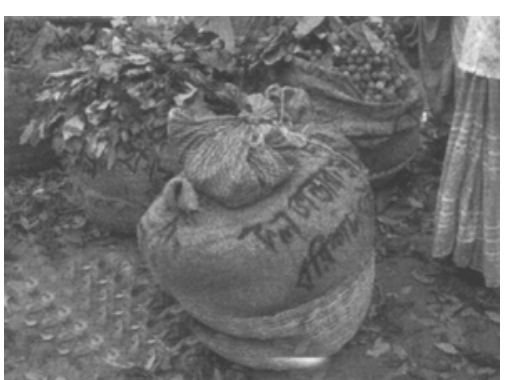

A

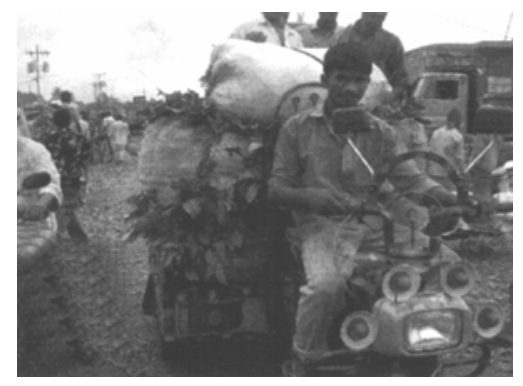

C

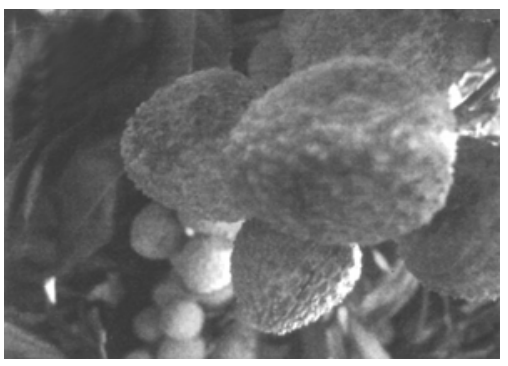

$\mathrm{E}$

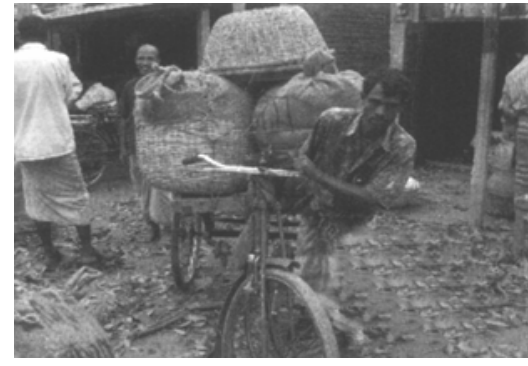

B

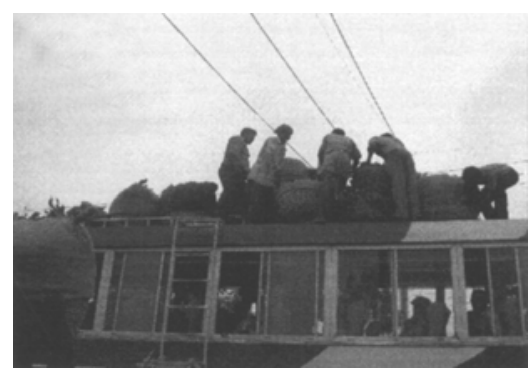

$\mathrm{D}$

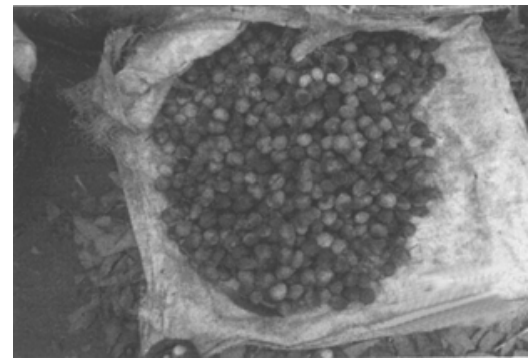

$\mathrm{F}$

Fig.1. A scenario of postharvest practices and losses of litchi:

a. Packaging, b. \& c. Local transportation, d. Distant transportation, e. Browning of fruit skin: lowers marketable value, f. Damaged and spoiled litchi after harvesting and handling from orchards 


\section{Losses during handling / transport from orchard (after harvesting) to selling point of local market}

The growers reported that the postharvest losses were $6 \%, 4 \%$, and $5 \%$ in Dinajpur, Ishurdi, and Natore after harvesting to carry litchis from orchard to local selling point. On the other hand, the beparies had 3\%, $2 \%$, and $1.5 \%$ losses during handling or transport fruits from orchard to the selling point in local market in those areas (Table 6). About 7\%, 4\%, and 6\% losses occurred at the arathdar's level in Dinajpur, Ishurdi, and Natore after carrying fruits from orchard to arathdars'shed. The grand average postharvest losses of litchi during handling the harvested fruits for carrying in the selling point of the local markets of three growing areas was $4.61 \%$. According to different groups of respondents, the nature of above losses were spoilage of edible portion of fruits i.e., arils, dropping the fruits from pedicel, damaging fruits through careless handling and browning of fruit skin that reduces market values.

Table 6. Postharvest losses of litchi at various groups of respondents with respect to different stage of handling /point of marketing.

\begin{tabular}{|c|c|c|c|c|c|c|c|}
\hline \multirow{3}{*}{$\begin{array}{l}\text { Stage of handling/ } \\
\text { Point of marketing }\end{array}$} & \multicolumn{7}{|c|}{ Percent losses at various groups of respondents } \\
\hline & \multicolumn{3}{|c|}{$\begin{array}{c}\text { Growers/beparies involved } \\
\text { in harvesting }\end{array}$} & \multicolumn{4}{|c|}{ Beparies not involved in harvesting } \\
\hline & Dinajpur & Ishurdi & Natore & Dinajpur & Ishurdi & Natore & Dhaka \\
\hline During harvesting & 10.0 & 8.0 & 6.0 & - & - & - & - \\
\hline $\begin{array}{l}\text { Handling/transport } \\
\text { from harvesting point } \\
\text { to selling point of } \\
\text { local market }\end{array}$ & 6.0 & 4.0 & 5.0 & 3.0 & 2.0 & 1.5 & \\
\hline $\begin{array}{l}\text { Handling/transport } \\
\text { from purchasing to } \\
\text { selling point of local/ } \\
\text { distant market }\end{array}$ & - & - & - & 2.0 & 1.5 & 1.0 & 5.0 \\
\hline $\begin{array}{l}\text { Buying to } \\
\text { consumption }\end{array}$ & - & - & - & - & - & - & - \\
\hline $\begin{array}{l}\text { Total losses (\%) at } \\
\text { different groups of } \\
\text { respondents in study } \\
\text { areas }\end{array}$ & 16.0 & 12.0 & 11.0 & 5.0 & 3.5 & 2.5 & 6.0 \\
\hline $\begin{array}{l}\text { Average losses at } \\
\text { different groups of } \\
\text { respondents in study } \\
\text { areas }\end{array}$ & & 13.0 & & & & 4.25 & \\
\hline
\end{tabular}




\section{Losses during handling/ transport from purchasing point of local market to selling point of local or distant market}

The average losses of litchi during handling or transport from purchasing point of local market to selling point of local or distant market were found $2 \%, 1.5 \%, 1 \%$, and $5 \%$ at the beparies level in Dinajpur, Ishurdi, Natore, and Dhaka. Arathdars in Dhaka City area had 4\% loss, but these groups of respondents in Dinajpur, Ishurdi, and Natore areas reported that they had no losses in their business sheds. Pikars were found only in Dhaka City and they had only 3\% losses. On an average, $3 \%, 3 \% 2.4$, and $8 \%$ losses were occurred at retailers' level in the study areas of Dinajpur, Ishurdi, Natore, and Dhaka City. The respondents opined that these losses were mostly caused by dropping of fruits from pedicel, spoilage of arils and browning of fruit skin and damaging through physiological disorders.

Table 6. Postharvest losses of litchis at various groups of respondents with respect to different stages of handling (Cont'd.).

\begin{tabular}{|c|c|c|c|c|c|c|c|c|}
\hline \multirow{3}{*}{$\begin{array}{l}\text { Stage of handling/ } \\
\text { Point of marketing }\end{array}$} & \multicolumn{8}{|c|}{ Percent losses at various groups of respondents } \\
\hline & \multicolumn{4}{|c|}{ Arathdar } & \multicolumn{4}{|c|}{ Pikar } \\
\hline & Dinajpur & Ishurdi & Natore & Dhaka & Dinajpur & Ishurdi & Natore & Dhaka \\
\hline During harvesting & - & - & - & - & - & - & & \\
\hline $\begin{array}{l}\text { Handling/ transport } \\
\text { from harvesting } \\
\text { point to selling } \\
\text { point of local } \\
\text { market }\end{array}$ & 7.0 & 4.0 & 6.0 & - & - & - & - & - \\
\hline $\begin{array}{l}\text { Handling! transport } \\
\text { from purchasing to } \\
\text { selling point of } \\
\text { local/ distant market }\end{array}$ & - & - & - & 4.0 & - & - & - & 3.0 \\
\hline $\begin{array}{l}\text { Buying to } \\
\text { consumption }\end{array}$ & - & - & - & - & - & - & - & - \\
\hline $\begin{array}{l}\text { Total losses (\%) at } \\
\text { different groups of } \\
\text { respondents in } \\
\text { study areas }\end{array}$ & 7.0 & 4.0 & 6.0 & 4.0 & & & & \\
\hline $\begin{array}{l}\text { Average losses at } \\
\text { different groups of } \\
\text { respondents in } \\
\text { study areas }\end{array}$ & & 5.25 & & & & & 3.00 & \\
\hline
\end{tabular}


Table 6. Postharvest losses of litchis at various groups of respondents with respect to different stage of handling (Cont'd.).

\begin{tabular}{|c|c|c|c|c|c|c|c|}
\hline \multirow[b]{3}{*}{$\begin{array}{l}\text { Stage of handling/ } \\
\text { Point of marketing }\end{array}$} & \multicolumn{7}{|c|}{ Percent losses at various groups of respondents } \\
\hline & \multicolumn{4}{|c|}{ Retailer } & \multicolumn{3}{|c|}{ Consumer } \\
\hline & Dinajpur & Ishurdi & Natore & Dhaka & \multirow[t]{2}{*}{ Dhaka } & Gazipur & $\begin{array}{l}\text { Average } \\
\text { losses of } \\
\text { different } \\
\text { stage of } \\
\text { handling }\end{array}$ \\
\hline During harvesting & - & - & - & - & & - & 8.0 \\
\hline $\begin{array}{l}\text { Handling/ transport } \\
\text { from harvesting } \\
\text { point to selling } \\
\text { point of local } \\
\text { market }\end{array}$ & - & - & - & - & - & - & 4.61 \\
\hline $\begin{array}{l}\text { Handling/ transport } \\
\text { from purchasing to } \\
\text { selling point of } \\
\text { local / distant } \\
\text { market }\end{array}$ & 3.0 & 3.0 & 2.4 & 8.0 & \multirow{2}{*}{$\begin{array}{l}- \\
9.0\end{array}$} & - & 3.90 \\
\hline $\begin{array}{l}\text { Buying to } \\
\text { consumption }\end{array}$ & - & - & - & - & & 6.0 & 7.50 \\
\hline $\begin{array}{l}\text { Total losses (\%) at } \\
\text { different groups of } \\
\text { respondents in } \\
\text { study areas }\end{array}$ & 3.0 & 3.0 & 2.4 & 8.0 & 9.0 & 6.0 & \\
\hline $\begin{array}{l}\text { Average losses at } \\
\text { different groups of } \\
\text { respondents in } \\
\text { study areas }\end{array}$ & 4.10 & & & & 7.50 & & \\
\hline
\end{tabular}

Losses after buying to consumption: The consumers in Gazipur and Dhaka areas reported that about 6 to $9 \%$ of litchi bought by them was non-consumable within 3 days after buying (Table 6). Usually the consumers bought 50 to 100 litchis at a time for their family numbers of 4 to 6 . Major number of litchis were consumed within the day of buying. The general practice of keeping the rest of the litchis is at ambient condition with or without in polyethylene bag. Most of the stored litchis lost their quality, even the storage life within 3 to 5 days. This is in agreement with Underhill et.al (1997). They mentioned that the short storage life of litchis under ambient condition ( 2 to 7 days at $25^{\circ} \mathrm{C}$ ) has been a significant impediment to litchi trade. Insect inside the fruits, spoiled arils, and browning of fruit skins (Fig. 1) and physiological browning of pulps that influences the 
negative choice of consumers were the major causes of non-consumption attitude to the consumers. These indicate the short storage life and rapid quality deterioration of harvested litchis at consumers' level. Snowdon (1990) reported that browning and disease continue to be the main limitations to litchi storage. Macfie (1955a, 1955b) also noted that litchi storage life was primarily limited by physiological browning and disease.

Average losses of litchi at growers, beparies, arathdars, retailers, and consumers level were found as $13.0 \%, 4.25 \%, 7.75 \%, 4.10 \%$, and $7.50 \%$ (Table 6 ) in the selected areas. From the Table 6, it revealed that the growers and/or beparies engaged in harvesting had the highest percent of losses in the growing areas (16\% in Dinajpur, 12\% in Ishurdi, and $11 \%$ in Natore). Consumers in two surveyed areas also had higher postharvest losses of litchis (7.5\%) for their short shelf life and quality deterioration. It could be mentioned here that times taken to reach the harvested litchi from the growing areas to the consumer of Dhaka City and Gazipur areas were only 1 to 3 days.

\section{Conclusion}

The postharvest practices followed by the growers and/or beparies were as precooling, sorting, and packaging in the surveyed area. All of the practices were locally developed. No standard practices of cooling and packaging were followed. The major portion of postharvest losses was appeared at harvesting mainly due to insect attack and disease as well as adverse weather stress before harvesting, but it expressed at harvesting. Careless harvesting and handling also may cause injuries and losses of marketable quality of litchis during harvesting and transports to different points. Due to short shelf life and rapid quality deterioration, a considerable portion of litchis also goes to waste after buying to consumption.

\section{References}

Amiruzzaman, M.1990. Postharvest handling and processing of fruits and vegetables. In: Kitchen Gardening and Homestead Productive Activities. CIRDAP Action Research Series No. 11. p.22.

BBS. 2006. Year Book of Agricultural Statistics of Bangladesh. Bangladesh Bureau of Statistics. Planning Division. Ministry of Planning, Government of the People's Republic of Bangladesh. p. 86.

Khader, A.A. 1992. Postharvest Technology of Horticultural Crops. 2nd ed. Univ. of California. Divn. of Agric and Natural Resurces. Publication.No.33 11.

Macfie, G.B. 1955a. Wrapping and Packaging of Fresh lychees. Florida Lychee. Growers’ Association Yearbook 1. pp. 25-28 
Macfie, G.B. 1955b. Packaging and storage of lychees fruits. Florida Lychee. Growers' Association Yearbook 1. pp. 44-48

Maiti, S.C. 1985. Litchi. In: Fruits of India. Tropical and subtropical, 1st edn. edied by T. K. Bose., Naya Prokash, Calcutta-6, India. pp. 405-406.

Momen, M.N., M.A. Rahim, A.M. Farooque and M. S. H. Choudhury. 1993. Effect of some coating materials and physical measures on the prolongation of shelf life of banana. Agric. 4(1-2): 41-51.

Snowdon, A. L. 1990. A colour atlas of postharvest disorders of fruits and vegetables Vol. 1. General Introduction and Fruits. Wolfe Scientific Ltd., London. pp. 126-127

Underhill, S. J. R., L. M. Coates and Y. Saks. 1997. Litchi In: postharvest physiology and storage of tropical and subtropical fruits. edited by S. K. Mitra, CAB International, Wallingford, Oxon OX1O DE, UK. pp. 191-203. 